\title{
Analysis on the Significance of Constructing Asian Infrastructure Investment Bank
}

\author{
Fei Wei \\ The Institute of Economics, Jinan University; Guangzhou, China \\ Email:244829589@qq.com
}

How to cite this paper: Wei, F. (2017) Analysis on the Significance of Constructing Asian Infrastructure Investment Bank. American Journal of Industrial and Business Management, 7, 283-299. https://doi.org/10.4236/ajibm.2017.73020

Received: February 21, 2017

Accepted: March 28, 2017

Published: March 31, 2017

Copyright (C) 2017 by author and Scientific Research Publishing Inc. This work is licensed under the Creative Commons Attribution International License (CC BY 4.0).

http://creativecommons.org/licenses/by/4.0/

(c) (i) Open Access

\begin{abstract}
Infrastructure construction is of great significance to a country's sustainable economic growth. As the economic globalization and regional integration, Asia has become the world's most active and most promising region, deepening of cooperation between countries, but pushing forward cooperation needs to rely on sound infrastructure system. However, most of the developing countries in Asia face difficulties, such as poor infrastructure, insufficient funds, which seriously restrict the economic development of Asian countries and weaken the ability to response to the financial crisis. Setting up an investment bank that provides special service on financing for infrastructure construction in Asian countries is particularly important, for China and Asia and even for the whole world; it has the far-reaching significance. The preparation of the Asian infrastructure investment bank is unprecedented, so we need to learn operation pattern and the structure of the organization of experience from the world bank and the Asian development bank and other international financial organizations, combined with the actual situation of the region. As a result, we should analyze the significance and carry on the reasonable and feasible ideas for the Asian infrastructure investment bank.
\end{abstract}

\section{Keywords}

The Asian Infrastructure Investment Bank, the Significance, International Financial Organization, the Construction of Infrastructure

\section{Introduction}

Today, the world structure tends to be diversified, and the economic and trade relations between countries are deepening, to enhance the competitiveness of cooperation to achieve the win-win situation. Through establishing a free trade area or the international financial organizations, countries cooperation relationships become more closely, and they hope to promote the development of econo- 
my by strengthening cooperation. With the acceleration of economic globalization and regional integration, Asia has become the most actively region in the world. Asia's population accounts for $60 \%$ of the world's total population, there have certain advantages in resources, energy. Since twenty-first century, whether before or after the financial crisis, compared with the current situation of the developed countries in the market downturn, the Asian developing countries show a strong investment scene, such as the rise of the BRIC countries. The Asian development countries that have strong growth and large investment space, also continue to strengthen economic and trade exchanges between countries; the establishment of Chinese ASEAN Expo, APEC, the Asian Development Bank and other organizations or agencies, which continue to promote economic and trade exchanges between Asian countries, promote the Asian integration process. With the establishment of the Inter American Development Bank, the European Investment Bank, the African Development Bank and other international financial organizations, and it have played an important role in the development of national economy in the region, however the Asian Development Bank is established in order to promote the economic development of the Asia Pacific region, for controlling under the developed countries such as Japan. The Asian Development Bank can not completely solve the real needs of developing countries in Asia, especially the demand for infrastructure construction. Therefore, there is an urgent need to establish an international financial institution that completely serves for the development of Asian developing countries especially infrastructure construction. As a result, investment bank came into being.

In Asia, most of countries have the weakness in infrastructure, and infrastructure construction is a high risk and long time, capital consumption project. Many developing countries are facing the dilemma of insufficient funds, and are unable to provide such a huge demand for funds only relying on the country's own resources. Therefore, on September 7, 2013, China President Xi Jinping's visit to Central Asia, first proposed the concept of Silk Road Economic Belt, on October 2nd, said talks with President Susilo in Indonesia, Jakarta, in order to promote regional interoperability and economic integration process. China proposes to build Asia infrastructure investment bank to provide funds for constructing infrastructure in developing countries, which it immediately received positive response of many Asian countries. After more than and 800 days of careful planning and efforts, on December 25, 2015, the Asian investment bank was formally established, and on January 16, 2016, it officially began operation.

The establishment of the Asian investment bank is of great significance for China and even the whole of Asia. In order to provide financing for infrastructure construction in Asian countries, It can solve the shortage of funds difficulties for many Asian developing countries, and help countries in the region to change the status of poor infrastructure, improve the country's infrastructure, strengthen the response to the rapidly changing world economic environment, enhance the ability to face financial risk, and also strengthen regional trade in goods and services trade, foreign investment, at the same time, accelerate the 
process of internationalization of the $\mathrm{RMB}$, which can reduce the dependence on the dollar yen, to promote Asian integration, to further enhance the rights and influence of Asia in the world, to change the oppressed situation, ultimately to promote the stability of the international situation.

In this paper, we analyze the current world situation and the Asian situation, and study the organizational structure and operation modes such as the Asian Development Bank, the world bank and the International Monetary Fund and other international financial organizations, based on the understanding of the weaknesses of these international financial organizations, to provide some ideas for the operation of the investment bank. This paper is divided into five parts, the first part is the introduction, a general description of the background of the Asian infrastructure investment bank and the significance for China and Asia and even the world; The second part is the literature review, we summarize the research of the Asian infrastructure investment bank from different angles, such as the significance or the design of the bank; The third part, according to the development status of the Asian, we analyze the limitations of international financial organizations in support of the Asian infrastructure, for example limited amount of funds, less financing channels and so on; The fourth part is the analysis of the significance of the establishment of the Asian infrastructure bank from Chinese and international perspective; The fifth part is based on the analysis of the world bank and the Asian Development Bank, and describes the challenges faced and puts forward some relevant suggestions. Final, the sixth part is the conclusion.

\section{Literature Review}

Asian infrastructure investment bank has become a hot spot in the current society, many domestic scholars have different views on Asian infrastructure investment bank from different angles. It is the first multilateral financial organizations that provide funds for constructing infrastructure in the region, which completely belongs to Asian developing countries. Lack of reference, we can analyze the Asian infrastructure investment bank from other international financial organization, such as the World Bank and the Asian Development Bank.

After World War II, many international financial organizations leading by developed countries such as the United States, for example, the World Bank, ADB, IDB, have played a positive role in promoting global economic recovery, reducing global poverty and other major areas. But, they are still inadequate. There have difference in the ADB between the reality and the goal, and the ADB has limited capacity in support of developing countries, can't meet the need in Asia that has a large poor population [1]; besides, the loans provided by the world bank are limited through analyzing the situation of the world bank, which leading a result that the supply can't meet the demand. But, the loans are concentrated in the developing countries that have relatively stable political environment or have a good investment benefit, while the developing countries who really need construction funds can't get the loans, finally there is the gap between 
rich and poor in the developing countries [2]; Nowadays, the developing countries, especially emerging market countries have very strong investment demand, and the demand for funds is very large, especially the demand of infrastructure after the financial crisis. However, there are many difficulties in the international financial organizations, such as the lack of capital financing, insufficient capital supply, for the two reasons: on the one hand, the international private capital can't enter developing or emerging market economies; on the other hand, there is an imbalance of savings between the developing countries, moreover, there is no effective bridge between the countries that savings surplus and the countries that lack of savings [3]; From the change of function and role of the world bank, believes that the world bank can't support the developing countries in the Asian region mainly because that the developed countries took control of the world bank, which is not fair to the countries that have different development degree [4].

Therefore, as the development of economic and investment in Asia, the establishment of the Asian Infrastructure Investment Bank has more significance. More and more scholars study it from different perspectives. Firstly, strengthening infrastructure construction will become a new growth point of the Asian economy in the future, and the construction of the Asian Infrastructure Investment Bank not only can deepen the cooperation between Asian countries, but also promote economic and trade relations, thereby expanding the RMB crossborder settlement, accelerate the process of internationalization of the RMB [5]; In addition, from the perspective of the relationship between western developed countries and developing countries in Asia, the Asian Infrastructure Investment Bank is promoting the economies of Asia, and this role played also refute the point of view about the Asian infrastructure investment bank was created to fight with the Asian Development Bank's [6]. Secondly, on the basis of the analysis of the ADB's organizational structure, source of funds and operation mode, learn from the advantages of the $\mathrm{ADB}$, and the Asian infrastructure investment bank is constructed for the purpose of promoting the development of Asia [2]; Moreover, from the principles of legal nature and system design of the Asian infrastructure investment bank, the construction of Asian infrastructure investment bank must take account of the actual situation of the developing countries especially the relatively backward countries, to achieve mutual benefit and win-win situation [6]. Finally, international financial organizations are made up of countries from different regions, there are different conflicts for interest, so, how to coordinate the conflicts of interest among member countries has becoming a key issue for scholars should pay more attention to, and is also a key issue in the operation of Asian investment bank. Though analyzing the voting rights of the members in the World Bank, and find that the largest proportion of the shareholding ratio are the United States, Japan, Germany, Britain and France, all are developed countries. For the major decision-making need more than $85 \%$ of the vote in order to pass through, the developed countries can add supplementary conditions or change loan conditions affecting economic and political decision-making of the develop- 
ing countries [1]; From the perspective of financial contribution of the ADB power distribution among the members, that through subscription ratio and financial contribution rate the $\mathrm{ADB}$ make the decision to vote, which is not reasonable. Although the voting mechanism is conducive to giving members the right to vote, this is not enough to explain the actual influence of ADB members in our country, and will be donated to members TIDA some political purpose means, is not conducive to the fairness of all members [7].

\section{The Limitations of International Financial Organizations}

\subsection{Large Capital Demand of Asian Countries}

Today, situation tends to be diversified, since 2008 after the financial crisis, developed countries showing economic decline, on the contrary, the booming developing countries, with the rise of developing countries and emerging countries, the developed countries influence is declining, while the developing countries influence on the rise. The pattern of the world has changed from the developed countries to the strength of the developed countries and the developing countries. How to dominate the most favorable in the new round of international shuffle, depends largely on the development of the economy, therefore, both at present and in the future is the most critical period of development of Asian developing countries, developing countries need to continue to deepen cooperation between construction and infrastructure construction, efforts to promote the interoperability of infrastructure construction. Can effectively promote the growth of poverty and promote sustainable economic growth plays a key role. The Asian area covers $60 \%$ of the total world population, economic output and trade volume has accounted for a large proportion in the world, is currently the world's fastest growing economy, has the most development potential of the region, thus attracting developed countries on the regional investment perspective, such as the United States joined ADB, by virtue of its holding the ADB the highest proportion of voting rights and to control the whole of Asia, also learned that many of the developed countries to join the Asian financial organizations are mostly hoping to get greater development in the Asian region.

Whether it is before and after the financial crisis, the market of the developed countries, the status quo of saturated investment downturn, while Asian countries are developing countries, most of the Asian countries are faced with the initial stage of city modernization and industrialization, or accelerated phase, the market is not saturated, investment space is large, and investment demand is very strong, especially is for energy, power and transport infrastructure in great demand, so the Asian area is currently considered the world's most active investment area. To be sure, now and in the future for a period of time, is the key period of developing Asia investment, the demand for capital will continue to increase, especially infrastructure investment needs will be very large, because the current Asian countries are actively pushing forward the Silk Road Economic Belt, Asia Pacific Supply chain establishment that will require infrastructure support for sound system. According to the Asian Development Bank, from 2010 
to 2020 , the Asian region requires an investment of $\$ 8$ trillion, of which $68 \%$ are used to add new infrastructure, $32 \%$ used to update existing equipment, covering the areas of energy, transportation, communications, which is equivalent to an annual average of $\$ 730$ billion will be needed. While the developing countries need for infrastructure construction funds are derived from the national financial support or ADB loans, financing channel is single, and the financing limit is limited, even the necessary funds can't meet, let alone the future quite a long period of time the funds needed for development needs.

\subsection{Limitations of International Financial Organizations}

The establishment and operation of international financial organizations, it is of great significance to the development of the global economy, especially to the development of developing countries, and it has played a significant role in solving the problem of energy resources, population, education, environment and other major areas. But it is inevitable that the international financial organizations still have some limitations in supporting the developing countries, especially in supporting the poorest developing countries. Based on the current situation of the developing countries in Asia, this paper sums up the limitations of the World Bank and Asian banks and the international monetary fund.

\subsubsection{Small Capital Coverage}

Small capital coverage has two meanings. On the one hand, refers to the international financial capital is very limited to invest in Asia, especially in relatively poor developing countries, that is, the development of funds in less. Asia has $60 \%$ of the world's population, while most of Asia is in very poor condition. It is understood that the bank loan is only $1 / 3$ to the Asian region, most of the loans are to India and Pakistan, other developing countries in Asia but rarely get the loan, such as the bank loans to Africa accounted for only $1.6 \%$ of the total amount of loans, and although the ADB said to belong to the Asian Development Bank, mainly for supporting and helping the Asian members, however, the United States and Japan, by virtue of its highest voting status on loan area restrictions, so the $\mathrm{ADB}$ loan is only concentrated in a few countries, can't cover all the Asian developing countries; on the other hand refers to money into infrastructure less. No matter what is the purpose of establishment, the world bank and the ADB's purpose now are committed to reducing poverty and promoting the development of the country or region, so the loan is mainly concentrated on the aspects of population, education, environment, resources and other major areas, and the management of infrastructure construction on the blonde although there are, but the limited amount of funds that can't meet the funding needs of developing countries in Asia. Overall, funding for infrastructure development in most developing countries in Asia, especially in relatively poor developing countries, is far less than the amount of money needed.

For example, Table 1, from the 2012 World Bank loan distribution table can be seen in the world bank funds are mainly concentrated in the public sector 
governance, legal and judicial aspects, while the construction of infrastructure investment accounted for only a small part of the information and communication, the proportion of less than $1 \%$.

In Table 2, from 2012, the ADB new loan amount distribution table to see the $\mathrm{ADB}$ at a relatively high level in the infrastructure investment proportion of new funds, such as the new investment on transportation and communication of information technology reached $31.3 \%$, but the actual increase in the amount of only $\$ 3666.2$ thousand, for a period of time in the future, the Asian infrastructure investment facing the huge demand for funds, the ADB new investment obviously is not enough.

\subsubsection{Limited Amount of Funds, Less Financing Channels}

The demand for investment in Asia is exuberant period in the future, especially in the Asian region between the "along the way", Asia Pacific Supply chain cooperation projects to actively promote, more needs to accelerate the construction of basis, according to the ADB data, from 2010 to 2020, the Asian area is required the

Table 1. The World Bank loan distribution in 2012.

\begin{tabular}{ccc}
\hline Loan field & Loan limit (\$100 million) & Proportion (\%) \\
\hline Public sector governance, law and justice & 87.3 & 25 \\
Energy and mining & 50 & 14 \\
Transportation & 44.5 & 13 \\
Health care and other social services & 41.9 & 12 \\
Water supply, sanitation and flood control & 36.1 & 10 \\
Agriculture, fisheries and Forestry & 31.3 & 9 \\
Education & 29.6 & 8 \\
Finance & 17.6 & 5 \\
Industry and trade & 13.5 & 4 \\
Information and communication & 1.6 & $<1$ \\
\hline
\end{tabular}

Table 2. New loans from the Asian Development Bank in 2012 (by region).

\begin{tabular}{ccc}
\hline Loan field & New loan amount (\$ millions) & Percentage of total new loan (\%) \\
\hline Multi sector & 461 & 3.9 \\
$\begin{array}{c}\text { Water supply, other municipal } \\
\text { infrastructure and services }\end{array}$ & 1206.25 & 10.3 \\
$\begin{array}{c}\text { Transportation and communication } \\
\text { information technology }\end{array}$ & 3666.2 & 31.3 \\
Finance & 775 & 6.6 \\
Energy & 2600.93 & 22.2 \\
Education & 177.6 & 2.4 \\
Agriculture and natural resources & 1040.1 & 8.9 \\
Health and social security & 70 & 0.6 \\
Ministry of industry and trade & 184.91 & 1.6 \\
Public sector management & 1435.59 & 12.3 \\
\hline
\end{tabular}


$\$ 8$ trillion investment and the huge amounts of money just provided by the bank and the $\mathrm{ADB}$ is not enough. We understand that the bank and the ADB funds mainly come from the capital, issuance of bonds, donated funds, loan interest and fee and a few asset investment income, besides, the ADB solves the shortage of funds by the application of joint financing and guarantee form, but it is out of the bank and the ADB aims to reduce poverty and promote the development of this region, the areas and fields need help and support are so extensive, as a result, funds unavoidably still a huge gap, let alone put the number of concentrated in infrastructure funds.

For example, in Table 3, the world bank is mainly composed of two major institutions of international bank for reconstruction and development and the International Development Association, from under the table, in the commitment, from 2011 to 2014, the international bank for reconstruction and development have declined overall, commitment on 2014 was $\$ 18,604$ million, although increased by $22 \%$ than in 2013 the $\$ 15,249$ million, but less than 2011 , the overall is still in a downward trend; and the International Development Association from 2011 to 2014 the commitment showing a rising trend, reaching \$22,239 million in $2014,36.7 \%$ more than in 2011 . In addition, we can see from the two institutions of the outstanding loans or not spending donations and annual commitment, to meet the future needs of Asia's $\$ 8$ trillion investment demand is far from enough.

\subsubsection{Strong Political Nature}

At present, the international financial organizations, mostly from the United States and other developed countries as the leading factor, such as the International Monetary Fund, is mainly dominated by the United States and some other

Table 3. The World Bank loan funds (\$ millions).

\begin{tabular}{|c|c|c|c|c|}
\hline International bank for reconstruction and development & 2011 & 2012 & 2013 & 2014 \\
\hline Commitment amount & 26,737 & 20,582 & 15,249 & 18,604 \\
\hline${ }^{\star}$ For development policy & 9542 & 10,333 & 7080 & 7997 \\
\hline Total expenditure & 21,879 & 19,777 & 15,830 & 18,761 \\
\hline${ }^{\star}$ For development policy & 10,582 & 9052 & 5972 & 9786 \\
\hline Principal repayment & 13,885 & 11,970 & 9470 & 9805 \\
\hline Net expenditure & 7994 & 7806 & 6361 & 8956 \\
\hline Outstanding loan & 62,916 & 62,916 & 61,306 & 58,449 \\
\hline International development association & 2011 & 2012 & 2013 & 2014 \\
\hline Commitment amount & 16,296 & 14,753 & 16,298 & 22,239 \\
\hline${ }^{\star}$ For development policy & 2032 & 1827 & 1954 & 2489 \\
\hline Total expenditure & 10,282 & 11,061 & 11,228 & 13,432 \\
\hline${ }^{\star}$ For development policy & 1944 & 202 & 1662 & 2644 \\
\hline Principal repayment & 2501 & 4023 & 3845 & 3636 \\
\hline Net expenditure & 7781 & 7037 & 7371 & 9878 \\
\hline Unpaid donation & 6830 & 6161 & 6436 & 6983 \\
\hline
\end{tabular}


organizations, although not dominated by the developed countries, but the developed countries have a relatively high proportion of cases of rights, such as the establishment of the ADB is to support and promote the Asian region and the economic development of countries in Asia, the United States and Japan are the highest stake, have great power in many resolutions on voting. Therefore, the current international financial organizations have a strong political color, which is reflected in the $\mathrm{ADB}$ and the World Bank loans have a certain tendency.

Loans tend to be biased, that is to say, when the financial institutions provide loans, because of the political factors, loans tend to be biased towards a particular country or region. It is understood that the support of the international financial organizations to the Member States mainly in the form of loans, and the form of loans in accordance with the rules and regulations of the financial institutions to set. For example, the ADB's loans are mainly made of hard loans, soft loans and donations, respectively, according to the different circumstances of the borrower to borrow. However, due to the limited funds of international financial organizations and the conflict of interest between the member countries, loans tend to be biased, resulting in the imbalance of loans. First of all, there are relatively few sources of funding of international financial organizations, the amount of funds is relatively small, which will result in the decision to invest more factors about the direction of loans and regions are considered. For example, the amount of money is relatively limited in providing loans, tend to provide funds for the regions that have high rate of return on investment, political stability and economic development condition, but the regions that really have a huge demand for funds are often the status of economic development, political chaos of the country, can only get a small part of the loan often, not enough to meet the huge demand of funds. Secondly, the international financial organization's members have different levels of development, or from different parts of the country, have many conflicts of interests for the differences about cultural, religious and political aspects, some countries coupled with financial organizations is not only to support the development of developed countries, but in order to achieve a political purpose or some aspects of the development. Therefore, it is easy to cause the country in the decision-making on the loan to consider their own interests and make the purpose of carrying out the vote. For example, the ADB is set up in order to support economic development in the Asia Pacific region, because Japan holds the highest vote, it is easy to make use of the right to vote by the United States or Japan, doesn't provide support the countries that hold the contrary political intentions, which seriously damage to the fairness. Now, the ADB loans are mainly concentrated in a few countries, but not for most countries, especially some relatively poor and backward countries or regions, for example, in 2008, the Asian Development Bank loans mainly consisting of India, China, Indonesia, Philippines, Vietnam and Pakistan, and for the relatively poor African countries were borrowing less.

In Figure 1, the world bank loan in many directions, selected three areas of finance, information and communications and transportation, analyzes the dis- 
tribution of new loans in 2012 in these three areas, it can be seen from the figure, in these three areas, Latin America and the Caribbean, Europe and Central Asia, new loans is an important proportion, the Middle East and North Africa, Africa that mostly in need of funds, are often the most difficult to obtain the loans.

Figure 2 also shows that IFC, one organization of the World Bank, is also prone to the regions that have high investment returns when make an investment decision, however, such as the Middle East and North Africa, South Asia, lack of investment in these areas. To sum up, the World Bank will consider the rate of return on investment and the power of the countries that has a high voting power, and the World Bank loan has a clear tendency.

\section{The Significance of Asian Infrastructure Investment Bank}

\subsection{The Significance in China}

China's influence in the world is more and more big, become the second largest economy after the United States, in recent years, China foreign investment continues to expand, the scale of Chinese investment scale is enlarged year by year,

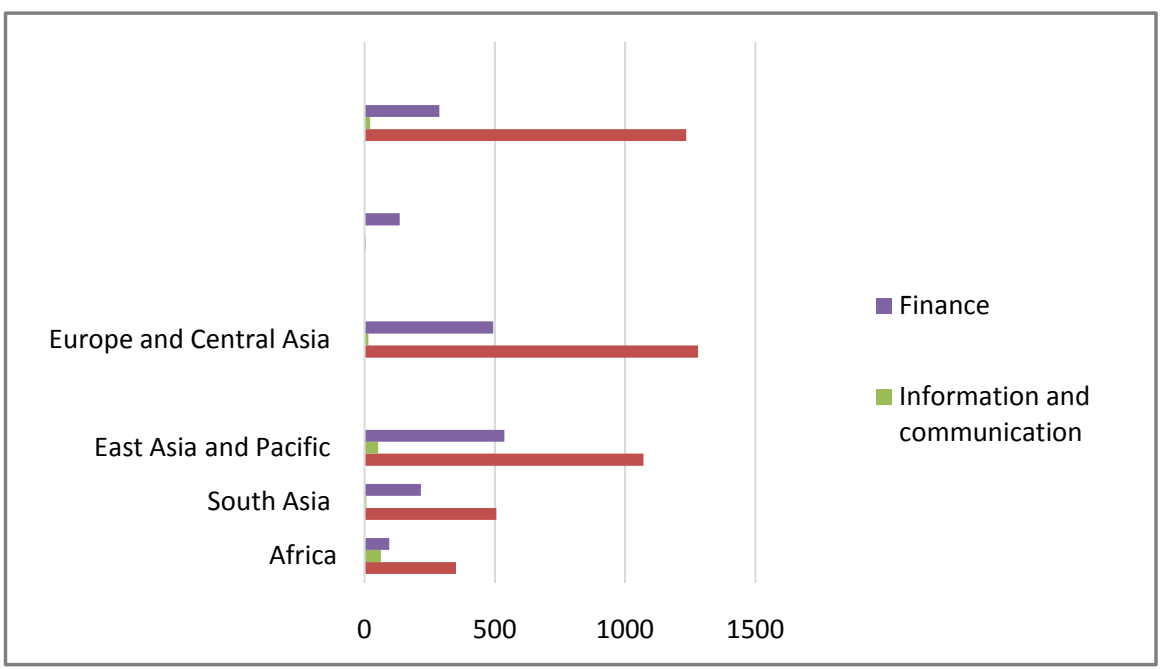

Figure 1. New loans to finance, information and communications, and transportation provided by the World Bank in 2012 (by region) (Unit: millions of dollars).

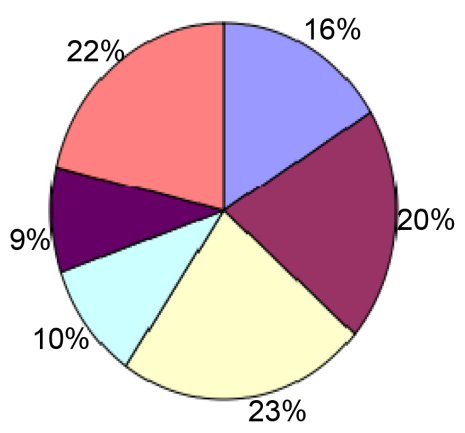

$\square$ East Asia and the Paci
fic
$\square$ Europe and Central Asi
a
$\square$ Latin America and the
Caribbean
$\square$ Middle East and North
Africa
$\square$ South Asia
$\square$ Sub-Saharan Africa

Figure 2. The World Bank IFC organization investment distribution in 2014 (by region). 
but in 2015 the foreign investment rate decline, domestic overcapacity phenomenon is prominent, Chinese is stepping up the pace of supply side reform, while expanding the scale of foreign investment to stimulate domestic economic development. The establishment of Asian infrastructure investment bank has a significant impact on China's economic development.

First of all, the current China economic development into a slowdown, infrastructure industries such as steel, cement and other industry overcapacity, and the form of international trade is becoming more and more serious, for example, the anti-dumping and countervailing investigations on Chinese enterprise, even to set all kinds of trade barriers to impede China on its export, which serious impact on China's export trade. The establishment of Asian infrastructure investment bank aims to establish multilateral trading system interoperability, focusing on the basic investment areas. Information that the first investment project of Asian infrastructure investment bank is $\$ 5$ billion, which China invested $\$ 2500$ million, evidently, investment projects contribute to the infrastructure construction materials to stimulate domestic export surplus, thus effectively digest excess capacity, promote the industrial upgrading, moreover, this is an effective way to help solve the problem of overcapacity in China's economy by meeting the demand of foreign market, which brings positive externalities, and becomes implementation of domestic supply side reforms.

Secondly, the RMB is an important part of the investment bank capital, in the construction of Asian infrastructure investment bank, it can make use of the RMB in the investment and loan, expand RMB settlement and the scope of investment, and contribute to the increase of cross-border RMB deposit scale, increase the supply of offshore RMB, accelerate the development of offshore RMB market cultivation, to accelerate the process of internationalization of the RMB. Besides, the RMB has become the main investment currency in the Asian region, which play the role of radiation surrounding, as the recognition of RMB become more and more high, RMB internationalization speed up, as a result, a virtuous circle to stimulate domestic demand and foreign trade using the go out of the $\mathrm{RMB}$; The increase of RMB using frequency at the same time, RMB loan interest rate will be affected by the international market and gradually realize the market, to further promote the market-oriented development of the RMB deposit interest rate, greatly promoting the development of national standardization process of RMB.

Thirdly, the investment bank is the first to put forward by the Asian countries belongs to Asian, more importantly, this is the key that China plays an important role in the international order and make a big move, not only in the Asian region, and even to the whole international, will has an important impact. Asian infrastructure Investment Bank members include not only the Asian developing countries, including western developed economies, such as Britain, Germany and other countries, by virtue of their own advantages to play a role, and actively promote the Asian infrastructure Investment Bank to support the construction of infrastructure in Asia. However, with the World Bank and ADB is distinguished, 
in the Asian infrastructure investment bank authorized capital of $\$ 100$ billion, Chinese initial subscribed capital target of $\$ 50$ billion, and accounted for 50\% stake, becoming the largest shareholder of Asian infrastructure investment bank. It indicates that China's international economic status is rising, the economic strength is increasing, and the right to vote and the right to speak of economic development are gradually improving, which has a significant impact on the international economic structure.

\subsection{The International Significance}

The World Bank, the International Monetary Fund and the Asian Development Bank and other international financial organizations are dominated by the developed countries. In the international financial organizations, the United States and Japan play the mainly control role. If Asian countries need to build their own infrastructure, they will seek help from Japan or international financial institutions dominated by developed countries. In the current international financial system, the discourse power of developing countries and emerging economies doesn't match their contribution to global economic growth. However, infrastructure construction has a huge rigid demand, large investment and long investment period, slow returns, only through the loans provided by the Asian Development Bank and the World Bank are not enough. Therefore, the establishment of Asian infrastructure investment bank is imperative. Asian infrastructure investment bank provides financing on infrastructure investment, to assist the objects in Asia region especially developing countries, in addition, it indirectly support to other international financial organizations, plays the complementary advantages with other international financial organizations.

On the one hand, Asia has the largest population in the world, with the development of economy, the economic and trade volume accounted for $1 / 3$ of the world, but its economic development has many problems, especially the lack of infrastructure construction outstanding, Such as India, Mongolia, Vietnam and other countries, their railway, ports, airports and communications and other aspects lack of investment, seriously restricting the economic development of these countries. Not only the Asian infrastructure investment bank support developing countries in the capital, will also output advanced technology to provide comprehensive support, that actively promote regional "Belt and Road Initiative" development strategy, promote the "Pan Asian community" development, promote the development of the whole industry chain composed of upstream manufacturing, midstream infrastructure, downstream services, finally, fully plays the key role in supporting the construction of infrastructure in developing countries in Asia; On the other hand, Asian infrastructure investment bank in the international sense is to improve and develop the existing international financial system. From the past to the present developed countries has been the world's leading Party and founder of the rules, the establishment of an investment bank is a key step to strengthen Chinese rulemaking authority in the Asia Pacific region, particularly, China has been actively promoting world peace, and advocating 
building peaceful international financial structure, so, building the Asian infrastructure investment bank, to further improve the status of developing countries and emerging economies in the world, and strengthen the cooperation with the developed countries on the basis of peace, establish a new investment and financing pattern, change a series of old rules of the world bank and the Asian Development Bank made by the developed countries, in final, create a new international political and economic situation in the new era.

\section{Operational Challenges and Recommendations}

\subsection{Avoiding the Political Nature}

According to the limitations of the analysis above, the world bank and ADB due to conflicts of political interests, resulting in the decision making process has strong political nature, the loan has a certain bias phenomenon, but mainly because the vote distribution in the bank and the ADB is unreasonable, unfair phenomenon between the developed countries and developing countries. The combination of the right to vote and the financial contribution, the ADB may reasonably allocate the financial contribution of the member states. In order to ensure the control of the local governments, it requires the local governments hold at least $60 \%$ of the voting rights. However, the way to determine the right to vote also makes the developing countries especially the poorest and most underdeveloped countries in a passive position. Because these countries in a poor situation, their domestic infrastructure construction is seriously insufficient, not to mention the financial contribution of the Asian Development Bank, while the developed countries have more funds, naturally the financial contribution rate up, as we can seen that the voting system will take into account the financial contribution but didn't change the passive status of developing countries. Therefore, it is of great significance to eliminate the phenomenon of political nature and ensure the fair distribution of loans.

\subsection{Increase Support Ways to Diversify Financing Channels}

Starting from the purpose of the establishment, the investment funds mainly invest in Asian infrastructure construction, but only support to help is not enough in the form of loan funds. According to the analysis, the World Bank and other international financial organizations, there is a shortage of funds; a large part of the reason is due to the lack of financing channels. In addition, most Asian countries are lagging behind economic development, lack of advanced technology, and advanced equipment, in infrastructure construction, have not advanced technology and equipment and a wealth of experience and funds combined, investment funds will also appear low efficiency. Therefore, on the basis of the $\mathrm{ADB}$ and the world bank and other international financial organizations experience, combined with the actual situation of Asian countries, the investment bank needs actively explore more diverse ways to support and improve the efficiency of the use of funds, expand access to funds, making all the favorable factors can participate in the construction of infrastructure in Asia. 


\subsubsection{A Combination of Investment and Loans}

At present, the international financial organizations mainly provide support to the member countries in the form of loans; inevitably, there are some risks in the form of loans, such as credit risk. It is understood that some countries especially the ability of poorer countries to repay the loan is very limited, partly due to the cost and benefit of the project funding is considerable, it is difficult to recover; partly because some countries will use the loan to other way, resulting that the project to completion and loan default. Therefore, the lessons learned from other financial organizations, the Asian infrastructure investment bank can provide the loans in the form of investment and loan combined, that is, while providing loans, the proportion of loans as investment in the project by the Asian infrastructure investment bank, however, it is important to ensure that the project units or the borrower take control of the implement, and Asian infrastructure investment bank can provide suggestions on the implementation of the project, even the technology or equipment. After the completion of the project, the Asian investment bank gets the income gains as loan interest repayment. The combination of investment and loans, can effectively supervise the implementation of the project, but also innovative ways to support, reduce credit risk, from another point of view, also increase additional funds for the Asian infrastructure investment bank

\subsubsection{Technical and Personnel Assistance}

In today's world, advanced technology and talent are the key elements of rapid economic development, want to achieve greater economic development, we need to work on these two aspects. The developed countries are leading in the world, but also because of its advanced technology and top high-tech talent, while most of the Asian countries are developing, and most of them are relatively backward, relatively slow economic development, so, the advanced technology and hightech talent make the economy rapid growth. Many international financial organizations lead by the developed countries support technical assistance as an important form for the development of the region. A technical assistance funds in ADB funding, specifically for meeting the technical demand in the country's economic development, improve the technical level of developing member countries or regions of Asia, at the same time, provide many services for the countries in the region or member states, such as personnel training, consulting services, and improve the project management ability of people management services. Therefore, learning from the experience of the $\mathrm{ADB}$, the Asian infrastructure investment bank provide the funds, and also try to set up technical assistance funds, to provide technology consulting, personnel training, personnel transport, donations of advanced equipment, economic exchanges and cooperation and other ways to support technical and personnel assistance for the developing countries in the region, speed up the construction of infrastructure.

\subsubsection{A Combination of Financing and Guarantee}

Developing Asia is facing a huge funding gap, relying solely on the investment 
bank's own funds, the issuance of bonds and donated the money is not enough, the loans providing for some political chaos and economic development relatively poor countries are often free or low interest, which has the potential risks, therefore, relative to the demand for funds, the supply of funds is not enough. It is understood that the Asian bank financing in the form of financing and guarantee, which effectively solve the problem of insufficient funds, but also for the international private capital provides a good intermediary to promote the flow of funds. Therefore, the Asian infrastructure investment bank can use the way supporting by $\mathrm{ADB}$, that is, joint financing and guarantee, for the construction of infrastructure of the country need funds to provide security, then these countries can raise funds for private financial institutions or private banks, or provide joint loans with private financial institutions or private capital. This way, not only can save money for an investment bank, putting money into the places that need more funds; but also further mobilize all the positive factors, so that promoting private capital and private capital actively participate in the construction of infrastructure, as far as possible to obtain funds to strengthen the flow of funds.

\subsection{Expand the Coverage of Funds}

It is understood that the world bank's investment funds in infrastructure construction coverage is small, the world bank loan funds mainly concentrated on agriculture, education and culture, and infrastructure construction funds are relatively small, and provided by the ADB for the developing countries especially the relatively poor countries the loans coverage is small, while investment in infrastructure funding is relatively more, but the money is mainly concentrated on a few developing countries, some countries are really in urgent need of funds can only get a small amount of money. Therefore, in the summary of the world bank and $\mathrm{ADB}$ funds invested, and give the two suggestions for the Asian infrastructure investment bank: on the one hand, the construction of "along the way" is going on, should focus on infrastructure construction, increase the transportation, information and communication and power facilities and other infrastructure investment, not only provide financial help, need more help by providing technology, advanced equipment and advanced teaching experience, promote the formation of infrastructure to strengthen the effects of radiation on the development of other industries; on the other hand, the members are distributed in Asia, Europe, Oceania, South America and Africa, consisting of the developing countries and developed countries, and the number of developing countries accounted for the major proportion. Therefore, from the point of view of the establishment, investment of the Asian infrastructure investment bank in Asia is mainly concentrated on the development of developing countries.

More importantly, the Asian infrastructure investment bank needs to keep on fair when making lending decisions, to review the reasonableness of investment projects to meet the loan conditions, and whether it can promote the development of the country's policy, and the bank can try to provide diverse support 
and help for the relatively poor developing countries. In addition, it is necessary to coordinate the conflicts of interest between regions and between developed countries and developing countries, and try to take into account the development of both sides to achieve a win-win situation.

\subsection{Properly Handle the Relationship with the United States and Japan}

In recent years, with the rapid development of economy, China economy overtake Japan, after the United States, in the rapid development of these years, China has accumulated rich experience in infrastructure construction, the construction efficiency is high, the introduction of advanced technology and many talents but also have sufficient funds to help other developing countries in infrastructure construction, promote common development and achieve mutual benefit and win-win. However, to the United States and Japan, and even many international organizations in the world, the establishment and development of the Asian infrastructure investment bank brings pressure to them to reform. For example, the United States realized that the future trend of the rise of Asia, and focus on the implementation of the "two kind of strategy", that is, construction of TTIP in the Atlantic (across the Atlantic trade and investment partnership agreement), and construction of TPP in the Pacific (trans Pacific Partnership Agreement), in addition, also launched APEC, return to Asia and many other measures to change the current international pattern, to continue to play a leading role in the future; a few months after the decision of the establishment of Asian infrastructure investment bank decided, Japanese Prime Minister Abe Shinzo announced that within the next five years will provide about $\$ 110$ billion to establish the Asian infrastructure fund to support construction of infrastructure in the Asian countries, in order to maintain the leading position in the Asian region, and hinder the process of the establishment of the Asian infrastructure investment bank. In addition, the Asian investment bank lack of experience in the formation and operation, especially the developed countries with rich experience is relatively small, selection, evaluation, operation and other aspects in infrastructure construction project are deficiency, it is Difficult to compete with international financial organizations led by the developed countries with a high level of development and experience. Therefore, the bank needs to learn from the world bank, the International Monetary Fund, the Asian Development Bank and other multilateral organizations, international financial organizations, learn these strengths, reasonable play bank's own advantages, and strive to improve their professional level, enhance and promote the construction of the Asian infrastructure in order to achieve the economic role of interconnection construction. Dispel the concerns about that the Asian infrastructure investment bank competes for hegemony in Asia, maintain stability and development of international economic pattern.

\section{Conclusion}

Asia is a not fully developed, has more room for developing in the area, but be- 
cause the Asian countries face with many shortage problems, such as poor infrastructure, lack of funds, lack of technology and talent, so the Asian region still belongs to the less developed. The Asian Infrastructure Investment Bank has a critical significance for the development of infrastructure in Asia for developing countries, which is not only good for the construction of the Silk Road Economic Belt and the maritime silk road, but also enhances the ability of developing countries to cope with the global economic change and to cope with the financial and economic crisis, thus, enhancing their ability to maintain sustainable economic growth. The establishment and operation of the bank, to be formed by China, the BRICs as a major force, and the developed countries as our auxiliary forces to coordinate the relationship between the developing countries and the developed countries, with the help for the Asian developing countries as much as possible, especially the poorest developing countries, is not only to help them complete the construction of infrastructure, to improve the effect of coping with risks and crisis, to reduce poverty and improve the living standards of the people, but also can accelerate the economic growth in the Asian region, the further development of Asia's potential, and promote global economic growth, accelerating global economic recovery.

\section{Acknowledgements}

Project No. 45015157: the project commissioned by 2016-2018 to improve the service capability of Guangzhou financial innovation service area.

\section{References}

[1] Huang, Z.Y. and Kuang, Y.J. (2013) "World Bank" on the Experience and Inspiration of the Establishment of the Asia Infrastructure Investment Bank. Southeast Asia, 3-10.

[2] Huang, Z.Y. and Kuang, Y.J. (2013) "Operation Analysis of the Asian Development Bank and the Enlightenment" on the Establishment of the Asia Infrastructure Investment Bank. Southeast Asia, 3-9.

[3] Bo, H.M. and Wei, X.H. (2015) China and Multilateral Development Financial System: Status and Role. Guangdong Social Sciences, No. 2, 5-13.

[4] Zhai, T. (2015) Role and Limitations of the World Bank's. International Financing, 20-22.

[5] Sheng, B., Zhu, X.Y. and High Tension between Foundation (2013) The Asian Infrastructure Investment Bank, Silk Road Economic Belt. China Customs, 12.

[6] Li, Z.Z. (2014) Asia Infrastructure Investment Bank Will Promote Global Economic Growth.

[7] Liu, X.H. (2013) Study on the Distribution of Rights among the Members of the Asian Development Bank. Southeast Academic, No. 1, 113-120. 
Submit or recommend next manuscript to SCIRP and we will provide best service for you:

Accepting pre-submission inquiries through Email, Facebook, LinkedIn, Twitter, etc. A wide selection of journals (inclusive of 9 subjects, more than 200 journals)

Providing 24-hour high-quality service

User-friendly online submission system

Fair and swift peer-review system

Efficient typesetting and proofreading procedure

Display of the result of downloads and visits, as well as the number of cited articles Maximum dissemination of your research work

Submit your manuscript at: http://papersubmission.scirp.org/

Or contact ajibm@scirp.org 